\title{
Revision of the genus Aoria Baly, 1863 (Chrysomelidae: Eumolpinae) from China and Indochina
}

\author{
Ревизия рода Aoria Baly, 1863 (Chrysomelidae: Eumolpinae) \\ из Китая и Индокитая
}

\author{
L.N.Medvedev \\ М.H. Медведев
}

Institute for Problems of Ecology and Evolution, Russian Academy of Sciences, Leninsky prospect 33, Moscow 119071, Russia. Институт проблем экологии и эволюции РАН, Ленинский проспект 33, Москва 119071, Россия.

KEY WORDS: Chrysomelidae, Eumolpinae, Aoria, China, Indochina, key, new species.

КЛЮЧЕВЫЕ СЛОВА: Chrysomelidae, Eumolpinae, Aoria, Китай, Индокитай, ключ, новые виды.

ABSTRACT. A key to Aoria Baly (including Osnaparis Fairmaire, 1889 and Pseudaoria Jacoby, 1908) from China and Indochina. includimg species new for science: A. laosica (Laos), A. cuprea, A. heinzi, A. marginipennis, A. panfilovi, A. nigromarginata (China), $A$. vietnamica (Vietnam), A. martensi, A. fulva (China) spp.n. Besides, a new species from North India - $A$. brancuccii sp.n. is described. Genus Enneaoria Tan, 1981 is a new synonym of Aloria Bryant, 1939.

РЕЗЮМЕ. Приводится ключ Aoria Baly (включая Osnaparis Fairmaire, 1889 и Pseudaoria Jacoby, 1908) из Китая и Индокитая. Описываются новые для науки виды: A. laosica (Лаос), A. cuprea, A. heinzi, A. marginipennis, A. panfilovi, A. nigromarginata, A. martensi, A. fulva (Китай), A. vietnamica (Вьетнам) spp.n., а также из Северной Индии: $A$. brancuccii sp.n. Род Enneaoria Tan, 1981 является новым синонимом Aloria Bryant, 1939.

\section{Introduction}

To the moment 5 Aoria-like genera are known: Aoria Baly, 1863, Osnaparis Fairmaire, 1889, Pseudaoria Jacoby, 1908, Aloria Bryant, 1939 and Enneaoria Tan, 1981 [Moseyko \& Sprecher, 2010]. Theoretically typical Aoria has unmargined sides of prothorax and transverse prosternum, in Osnaparis prothorax is entirely margined, in Pseudaoria prosternum is quadrate and elytra tuberculate or nodose, at last genera Aloria and Enneaoria have 9-segmented antennae. However Enneaoria is a new synonym of Aloria, because author of Enneaoria overlooked Bryant's description.

Other 3 genera, having 11-segmented antennae. I prefer to accept as one genus with 3 subgenera. In Aoria s.str. a few species have partly margined sides of prothorax and very alike at Osnaparis, which was described earlier as a subgenus of Aoria. A form of pros- ternum also varies enough between quadrate and transverse form, as well as elytral sculpture, so in many cases Pseudaoria is very poorly divided from Aoria s.str.

Keys for Aoria were published for China [Gressitt \& Kimoto, 1961; Tan, 2005] and Indochina [Kimoto \& Gressitt, 1982; Eroshkina, 1987], but all they need revision.

A form of aedeagus, which earlier practically was used only for Vietnamese species [Eroshkina, 1987], in most cases is a good character for species dividing.

Species of this genus are strictly Oriental, but a few species reach southeast Palearctic (China and Japan). Fauna of China is unusually rich: 28 species with 23 endemics $(82 \%$ !). Other regions are much more poor: 8 in Vietnam, 4 in North India, Burma and Taiwan, 3 in Laos and Thailand, 2 inCambodia, Nepal and Malacca, 1 in Japan, Sumatra and Borneo.

Foodplants are known only for a few species [Medvedev \& Dang Thi Dap, 1982; Medvedev, 1983], but in all cases it was registered on Vitaceae.

Following abbreviations are used for the depository places: LM - author's collection, Moscow, Russia; NHMB - Naturhistorisches Museum Basel, Switzerland; PR - P. Romantsov's collection, Saint-Petersburg; SMNS - Staatliches Museum für Naturkunde, Stuttgart, Germany.

\section{Taxonomy}

\section{A KEY TO SPECIES}

1 (10) Sides of prothorax entirely margined (subgenus Osnaparis Fairmaire, 1889).

2 (9) Upperside red or fulvous, prothorax has same color as elytra.

3 (4) Antennae entirely fulvous. Body red. Head and prothorax coarsely and sparsely punctate. Elytra with regular rows of punctures, interspaces broad and glabrous. Length 6.0-6.5 mm. China: Yunnan ......... A. (O.) lushuiensis Tan, 1992

4 (3) Antennae black with 3 or 4 basal segments fulvous. Legs black, basal or large part of femora red. 
5 (8) Labrum and apical segment of maxillar palpi black.

6 (7) Antennae short and slender, slightly exceeding half of body length. Prothorax finely and densely punctate. Elytra with regular rows of shallow punctures, each puncture surrounded with dark ring. Length $5.5-6.3 \mathrm{~mm}$. China: Sichuan. 3 known 90 were collected on altitude 2300 $2700 \mathrm{~m}$. Possibly identical with the next species. $\sigma^{7}$ unknown ............................... A. (O.) montana Tan, 1992

7 (6) Antennae of $O^{\top}$ are about 0.8 of body length of $P-0.6$ 0.8 of body length. Prothorax densely and more strongly punctate. Elytra with less regular rows of deep punctures, not surrounded with dark ring. Aedeagus broadly rounded on apex (Fig. 1). China (Sikang, Sichuan, Hupeh, Kiangsi, Hopei ), North Vietnam, Japan, Taiwan (A. taliana Pic, 1935) ............................ A. (O.) nucea Fairmaire, 1889

8 (5) Labrum and apical segment of maxillar palpi fulvous. Body fulvous or reddish fulvous. Elytra with regular rows of punctures and almost impunctate interspaces. Length 4.9-5.2 mm. North Vietnam, Taiwan, Thailand. (A. tonkinea Pic, 1935) ............. A. (O.) pallidipennis Pic, 1928

9 (2) Upperside bicolor prothorax red to dark red, elytra fulvous. Head, underside and femora red, tibiae and tarsi black. Elytra with regular rows of punctures and narrow impunctate interspaces. Apex of aedeagus truncate with central tip (Fig. 2). Length of body 5.7-6.5 mm. Laos . A. (O.) laosica sp.n.

10 (1) Sides of prothorax not margined or pertly margined.

11 (18) Elytra sparsely covered with hairs, with transverse rugosities, wrinkled or tuberculate. Prosternum quadrate, mesosternum transverse (subgenus Pseudaoria Jacoby, 1908).

12 (13) Body metallic blue, elytra with cupreous sheen. Antennae black with 3 basal segments more or less fuscous, legs black or femora with metallic sheen. Prothorax coarsely punctate, with a few irregular and smooth calli on each side. Elytra with transverse depression and small, dense and confused punctures, without rugosity. Length $6.0 \mathrm{~mm}$. China: Sichuan ................. A. (P.) irregulare Tan, 1992 13 (12) Body without metallic color.

14 (15) $\sigma^{7}$ with an erect brush of fulvous long hairs on each side of third abdominal sternite (Fig. 18). 2 forms: black, sometimes frons and part of femora reddish or fulvous with apex of femora, tibiae and tarsi black; both forms with black antenna having apices of fore basal segments fulvous. Prothorax densely pubescent and rugosely punctate. Elytra coarsely and irregularly punctate with fine wrinkles behind humerus; basal depression indistinct. Apex of aedeagus truncate with distinct central tip (Fig. 3). Length 5.2-6.5 mm. China: Sichuan, North Yunnan. See also item 40 ........................ A. (P.) floccosa Tan, 1992

15 (14) $\sigma^{7}$ without hairy brushes on abdomen. Body red fulvous or chestnut brown.

16 (17) Head coarsely punctate, prothorax uneven, coarsely rugose, with strong punctures in depressed areas. Elytra with irregular rows, their interstities partly with longitudinal ridges, partly with irregular rugosity. Reddish fulvous, slightly paler on upper part of head and sides of prothorax. Length $4.5 \mathrm{~mm}$. China: Sichuan .....

A. (P.) rufina Gressitt \& Kimoto, 1961

17 (16) Head finely and densely punctate, prothorax very finely and densely punctate, with fine wrinkles. Elytra with irregularly arranged and unequal sized punctures, finely wrinkled throughout except inner middle portion. Chestnut brown, antennae except 4 basal segments, broad transverse band near anterior margin of prothorax, apices of femora, tibiae and tarsi black. Length $6.5 \mathrm{~mm}$. China: Yunnan ............................. A. (P.) yunnana Tan, 1992

18 (11) Elytra densely covered with hairs, without wrinkles, both pro- and mesosternum transverse (subgenus Aoria s.str.).

19 (26) Upperside entirely or partly with distinct metallic color.

20(23) Upperside entirely with metallic color.

21 (22) Upperside blue. Sides of prothorax margined at base. Elytra at sides with two ridges. Pubescence grey. Length about $6 \mathrm{~mm}$. China: Kansu

A. (s.str.) cyanea Chen, 1940

22(21) Upperside bronze. Sides of prothorax unmargined or feebly margined in middle. Elytra on sides with one ridge. Pubescence white. Aedeagus - Fig. 4. Length 5.1-6.1 mm. China: Sichuan, Yunnan .... A. (s.str.) cuprea sp.n.

23(20) Upperside not entirely metallic.

24(25) Head and prothorax bronze, elytra red. Femora and tibiae red with black apices, tarsi black. Sides of prothorax emarginated in anterior half. Length $6.8 \mathrm{~mm}$. China: Sichuan..... A. (s.str.) heinzi sp.n.

25(24) Upperside bronze with broad reddish margin of elytra (Fig. 19). Legs red. Sides of prothorax margined in middle. Length 6.6-7.6 mm. China: Sichuan ....

A. (s.str.) marginipennis sp.n.

26(19) Upperside without metallic color, rarely with feeble metallic tint.

27(28) Upperside red with black spots: central spot on prothorax (very rare absent) and 5 or 7 on elytra, 1 or 2 at base, 1 common on suture (rarely absent) and 1 lateroapical, posterior spots might be connected (Figs 20-23), posterolateral spot usually very shining and not pubescent, rarely densely pubescent (ab. larvatus Gressitt \& Kimoto, 1961). Antennae fulvous, legs red. Aedeagus - Fig. 5. Length 5.0-6.0 $\mathrm{mm}$. South China, Indochina, Taiwan, India, Burma, Malacca, Borneo. Feeding on Vitaceae. (A. quinquemaculata Bates, 1866, A. larvatus Gressitt \& Kimoto, 1961) .............. A. (s.str.) bowringi Baly, 1867 28 (27) Elytra without black round spots.

29 (36) Elytra bicolor. Sides of prothorax unmargined.

30 (33) Body larger than $6 \mathrm{~mm}$. Prothorax mostly with black spot.

31 (32) Elytra black with small elongate spot on humeral tubercle and apex red (Fig. 24). Head red with black sides and labrum, prothorax red with black spot near base before red scutellum, breast including prosternum black, abdomen red including all tergites with two black spots on the first sternite, legs black, pubescence golden. Elytra rather finely and not densely punctate, with humeral ridge going a little behind middle of elytra. Length $7.3 \mathrm{~mm}$. China: Sichuan ....................... A. (s.str.) panfilovi sp.n.

32 (31) Elytra red with two black pattern of irregular form, pertly connected or with black side margin (Figs 25, 26). Head red, prothorax red, sometimes with small black spot in middle, scutellum red, pygidium, underside including prosternum and legs black, abdominal tergites red. Elytra strongly, densely and confusedly punctate, punctures partly in irregular rows, humeral ridge indistinct. Aedeagus - Fig. 6. Length 6.2-6.3 mm. China: Fukien ........

$$
\text { A. (s.str.) nigromarginata sp.n. }
$$

33 (30) Body not more than $5.0 \mathrm{~mm}$. Prothorax without black spots.

34 (35) Elytra fulvous, narrowly black along lateral margin and suture, with regular rows of coarse punctures, interstities distinctly raised and costate. Prothorax with trans- 
verse furrow behind anterior margin. Legs piceous with femora except apices red. Length $4.5 \mathrm{~mm}$. China: Hunan A. (s.str.) costata Tan, 1992

35 (34) Elytra black with red sides. Punctures of elytra arranged in regular or irregular rows, interstities not costate. Legs black or middle of femora red. Length $3.8-5.0 \mathrm{~mm}$. China. (A. diversipes Pic, 1935; A. pectoralis Pic, 1935). See also item 65 ............................ A. (s.str.) annulipes Pic, 1935

36 (29) Elytra unicolor.

37 (44) Elytra black.

38 (43) Body black, only a few basal segments of antennae more or less fulvous. Sides of prothorax unmarginate.

39 (42) Elytra not costate on sides.

40 (41) Third abdominal sternite of $\sigma^{\top}$ with two brushes of long and erect hairs near hind margin (Fig.18). Elytra elongate, about 1.4 times as long as wide, practically parallel-sided in anterior two thirds, broadly rounded on apex, coarsely and confusedly punctate, partly rugose behind scutellum. Aedeagus (Fig. 3) with straight truncate apex, not grooved longitudinally on underside, in lateral view distinctly curved in apical part. Length 5.2-6.5 mm. Specimens with sides of prothorax indistinctly margined. China: Yunnan. See also item 14 ................... A. (P.) floccosa (Tan, 1991) (pars)

41 (40) Third abdominal sternite of $O^{7}$ simple. Elytra less elongate, 2.2 times as long as wide, distinctly narrowed to behind, strongly punctate, punctures arranged in irregular but distinct rows. Aedeagus with feebly concave truncate apex, longitudinally grooved on underside, in lateral view with straight apical part (Fig. 7). Length $4.6-4.8 \mathrm{~mm}$. China: Yunnan, North Vietnam: Shapa

A. (s.str.) atra Pic, 1923

42 (39) Elytra with two lateral costate on sides, with almost regular rows of punctures. Length $6.1 \mathrm{~mm}$. China: Hunan . A............................. A. (s.str.) carinata Tan, 1993

43 (38) Head and prothorax fulvous or red. Body black including pygidium, basal segments of antennae reddish, abdominal tergite red, elytra and underside might be with feeble blue tint. Antennae thin and long, almost reach apex of elytra preapical segments not thickened, about 3.5-4 times as long as wide. Side margins of prothorax not margined. Elytra with distinct, but not quite regular rows, without humeral ridge. Aedeagus - Fig. 8. Length 4.5$5.8 \mathrm{~mm}$. China: Fukien, Kwantung, Kwangsi

$$
\text { A. (s.str.) nigripennis Gressitt \& Kimoto, } 1961
$$

44 (37) Elytra fulvous or red, sometimes suture slightly darkened.

45 (52) Prothorax black. Side margins of prothorax unmarginate.

46 (47) Anterior and posterior margins of prothorax more or less reddish. Elytra fulvous with darkened suture and regular rows of punctures. Aedeagus with elongate-triangular apex (Fig. 9). Length 4.3-4.7 mm. North Vietnam: Cuc-Phuong ................ A. (s.str.) vietnamica sp.n.

47 (46) Prothorax entirely black. Aedeagus with truncate apex bearing small central top. Elytra usually red.

48 (49) Elytra with very distinct basal convexity, with punctures arranged in regular, more or less paired rows, with interspaces practically impunctate, underside red, legs black, hind femora might be red basally. Aedeagus with triangular apex (Fig. 10). Length 5.5-7.0 mm. South China (Sikang, Kweichow, Hupeh, Kiangsu, Chekiang). See also item 63. ............. A. (s.str.) rufotestacea Fairmaire, 1889 (pars)

49 (48) Elytra without distinct basal convexity, punctures not arranged in regular rows with interspaces very closely punctate. Aedeagus - Fig. 11. Legs black. Feeding on Vitaceae, including Cayratia.
50 (51) Underside red. Length 5.6-6.6 mm. South-east China, west to Sichuan, north and central Vietnam A. (s.str.) scutellaris Pic, 1923

51 (50) Underside black. Length 5.5-6.5 mm. China: North Sichuan .... A. (s.str.) scutellaris ssp. rufipennis Pic, 1923 52 (45) Upperside red or fulvous.

53 (56) Upperside with feeble metallic sheen.

54 (55) Elytra without postbasal depression, punctures strong and dense, rows hardly distinct because of closely punctate interspaces, pubescence dense, subadpressed. Antennae slender with preapical segments only slightly thickened. Body red brown with slight cupreous sheen, 7 apical antennal segments and tarsi piceous. Smaller, length 3.8-4.2 $\mathrm{mm}$. China: Shangtung ...... A. (s.str.) gracilicornis Chen, 1940

55 (54) Elytra with well developed postbasal impression, punctures deep and dense in basal part, but much sparser and quite feeble apically and along suture, pubescence very sparse and erect. Antennae with preapical segments thickened, about twice as long as wide. Body dark red, head and prothorax darker than elytra, light piceous with feeble metallic sheen, legs reddish including tarsi. Larger, length 5.3-6.1 mm. China: Shaanxi .... A. (s.str.) martensi sp.n.

56(53) Upperside without metallic sheen.

57 (58) Upperside fulvous. Body small, 3.4-3.7 mm. fulvous with 7 apical segments black. Elytra densely and confusedly punctate, without distinct rows. Aedeagus with rounded apex, having only a trace of central tip (Fig. 12). China: Shansi ............................... A. (s.str.) fulva sp.n.

58 (57) Upperside red.

59 (60) Preapical antennal segments about 1.1 times as long as wide. Underside and legs black, abdomen sometimes reddish on sides and in middle. Elytra densely punctate, partly arranged in rows, which are not very distinct among dense punctures. Aedeagus - Fig. 13. China: Chekiang, Kiangsi ..................... A. (s.str.) antennata Chen, 1940

60 (59) Preapical antennal segments at least twice as long as wide.

61 (62) Legs entirely black, underside red or sometimes more or less blackish on breast. Elytra without basal convexity. Pubescence dense and adpressed. Aedeagus - Fig. 14. Length 4.2-5.8 mm. South China, Vietnam, Laos, Cambodia, Thailand, Burma, India, Nepal, Taiwan, Malacca, Sumatra. Feeding on Vitaceae. (A. rufula Motschulsky,1866, A. fuscula Motschulsky, 1866, A. mouhoti Baly, 1878; A. pusilla Lefevre, 1889, A.bicolor Pic, 1935, A. taiwana Chujo, 1956; also very doubtful synonyms A. nigrita Jacoby, 1892 \& A. fulvifrons Jacoby, 1892 from India and Burma) ........... A. (s.str.) nigripes Baly, 1860

62 (61) Legs bicolor, rarely entirely black, but then elytra with basal convexity.

63 (64) Elytra distinctly raised at base, with well developed postbasal impression, almost regular rows of punctures with interstities almost impunctate, pubescence sparse and erect or suberect. Head mostly black or with red frons, underside red, legs black with red femora (except apices) or entirely black. Aedeagus with triangular apex (Fig. 10). Length 5.5-7.0 mm. (A. chinensis Jacoby, 1890; A. rufa Pic, 1928; A. lemoulti Pic, 1930; A. testacea Pic, 1935). See also item 48

A. (s.str.) rufotestacea Fairmaire, 1889 (chinensis form)

64 (63) Elytral sculpture different, but never with combination of regular rows and almost impunctate interspaces.

65 (66) Prosternum black. Legs black or femora with red mid part. Length 3.8-5.0 mm. China. See also item 35 ............... A. (s.str.) annulipes Pic, 1935 (fulvous form) 
66 (65) Prosternum red. Femora red, mostly with black apices.

67 (68) Elytra more broad (1.3 times as long as wide and 2.2 times wider than prothorax), parallel-sided with broadly rounded apices, pubescence dense and adpressed, surface with almost regular rows of punctures and densely punctate interspaces, not longitudinally costate except short ridge going from humerus. Aedeagus - Fig. 15. Length 5.6-6.6 mm. Vietnam (from north to Darlak province) A. (s.str.) bicoloripes Pic, 1935

68 (67) Elytra narrower (1.5 times as long as wide and 2.4 times wider than prothorax), distinctly narrowed to behind, with much more sparse and erect hairs, surface with irregular and less distinct rows and longitudinal folds or ridges. Prothorax densely and rugosely punctate. Possible aedeagus (specimen from Yunnan) — Fig. 16. Length 5.0-5.8 mm. China: Tibet, Yunnan .

A. (s.str.) thibetana Pic, 1928

\section{Descriptions of new species and taxonomical notes}

\section{Aoria (Osnaparis) laosica Medvedev sp.n.}

Fig. 2.

MATERIAL. Holotype $\left(\sigma^{7}\right)$ : Laos, Khammouang Prov., Ban Khounkhan (Nahin), $18^{\circ} 13 \mathrm{~N}, 104^{\circ} 31^{\prime} \mathrm{E}, 200 \mathrm{~m}$, IV.2005, leg. O. Gorbunov (LM). Paratypes: 4 ex., same locality (LM); 1 ex., Laos, Louangnamtha, Nantha-Muang Sing, $21^{\circ} 9^{\prime} \mathrm{N}, 100^{\circ} 19^{\prime} \mathrm{E}, 900$ 1200 m, 5-31.V.1997, Vít Kubáń leg. (NHMB); 1 ex., Laos, Phongsaly prov., Phongsaly env., $21^{\circ} 41 \mathrm{~N}, 102^{\circ} 6-8^{\prime} \mathrm{E}, 1500 \mathrm{~m}$, 28.V-20.VI.2003, leg. Pacholátko (NHMB).

DESCRIPTION. Head, prothorax and scutellum reddish to dark red, antennal black with 3 basal segments reddish, at least beneath, elytra fulvous, underside including pygidium and tergites and femora red, tibiae and tarsi black, pubescence fulvous.

Head rather sparsely punctuate, especially on clypeus, and microsculptured, supraantennal swellings flat and sometimes not quite distinct, anterior margin of clypeus almost straight. Antennae reach middle of elytra, proportions of segments are as 15-9-12-20-20-16-16-16-16-16-19, and five apical segments very feebly thickened, preapical segments about 3.5 times as wide as long. Prothorax 1.15 times as long as wide, broadest in middle, sides rounded and entirely marginate, surface densely punctuate with interspaces flat and without microsculpture. Scutellum trapeziform and punctuate. Elytra 1.5 times as long as wide, broadest in humeral area, with regular rows of punctures and narrow impunctate interspaces, basal convexity very feeble. Aedeagus with truncate apex bearing central tip (Fig. 2). Length of body $5.7-6.5 \mathrm{~mm}$.

DIAGNOSIS. Differs from all species of subgenus Osnaparis with bicolor upperside and from $A$. nucea Fairmaire also with quite different form of aedeagus.

\section{Aoria (s.str.) cuprea Medvedev sp.n.} Fig. 4.

MATERIAL. Holotype ( $\left.\sigma^{7}\right)$ : China, Yunnan, Heishui, $35 \mathrm{~km} \mathrm{~N}$ of Lijiang $\left(27^{\circ} 13^{\prime} \mathrm{N}, 100^{\circ} 19^{\prime} \mathrm{E}\right), 1-19 . \mathrm{VII} .1992$, leg. S. Becvar (LM). Paratypes: 2 ex., same locality (LM); $\sigma^{7}$, China, Yunnan, 30 km N Lijiang, 3000 m, 30.V.2002, leg. Volkovich (PR); 1 ex. Yunnan Yulongshan mts. (27 $\left.10^{\prime} \mathrm{N}, 100^{\circ} 13^{\prime} \mathrm{E}\right), 3500-4000 \mathrm{~m}, 16$ 19.VI.1993, leg. Vít Kubáň, (NHMB)

DESCRIPTION. Bronze or dark bronze, sometimes with feeble greenish tint or head and prothorax bluish, antennae black with 3 basal segments fulvous beneath, underside and legs black with bronze tint. Pubescence white.
Head strongly punctuate, with very thin microsculpture and smooth swelling on each side above antennal base, labrum with a row of punctures along anterior margin. Antennae almost reach middle of elytra, proportions of segments are as 12-8-9-15-15-14-14-13-12-12-16, preapical segments about twice as long as wide. Prothorax 1.4 times as wide as long, broadest in middle, side margins evenly rounded, with strong, deep and dense punctures and narrow, flat and shining interspaces. Scutellum triangular, rounded truncate apically, strongly punctuate. Elytra 1.4 times as long as wide, subparallel and broadly rounded on apex, strongly and confusedly punctuate in anterior half, more finely behind middle, partly in short irregular rows, with more or less distinct fold going from humeral tubercle to mid of elytron parallel to side margin. Aedeagus (Fig. 4) with roundedtruncate apex bearing short apical tip, strongly curved in lateral view. Length of body 5.1-6.1 mm.

DIAGNOSIS. Seems to be near to unknown to me A. cyanea Chen, 1940 from Kansu, which however has blue color and two ridges on elytra. I have also 2 of from South Sichuan, which however not included in the type series.

\section{Aoria (s.str.) heinzi Medvedev sp.n.}

MATERIAL. Holotype (sex not determined): China, Sichuan, Emei-Shan, 2100-2300 m, Thunder cave, 9-12.VII.1995, leg. Heinz (LM).

DESCRIPTION. Head, prothorax and scutellum bronze, maxillar palpi fulvous with black apical segment, antennae black with segments 1-3 fulvous beneath, elytra red, pygidium and underside black, femora and tibiae red with black apical third, tarsi black, hairs of upperside white.

Head strongly punctuate, distinctly microsculptured, with usual supraantennal swellings, labrum with a row of punctures on anterior margin. Antennae reach anterior third of elytra, proportions of segments are as 15-10-10-19-1615-13-13-13-13-14, preapical segments about 2.5 times as long as wide. Prothorax 1.1 times as wide as long, broadest in middle, side margins evenly rounded, feebly bordered in anterior half, unbordered behind middle, surface shining, with strong dense punctures and narrow interspaces. Scutellum elongate trapeziform, strongly punctuate. Elytra 1.55 times as long as wide, slightly widened from base to apical third, broadly rounded apically, surface shining, strongly punctuate, punctures along suture arranged in two almost regular rows, in middle and on sides confusedly punctuate with traces of rows, there is very feeble fold from humeral tubercle to middle of elytron; hairs long, erect, arranged in almost regular longitudinal rows. Length of body $6.8 \mathrm{~mm}$.

DIAGNOSIS. Differs from all known species with combination of metallic bronze prothorax and red elytra.

\section{Aoria (s.str.) marginipennis Medvedev sp.n.} Fig. 19.

MATERIAL. Holotype ( $(+)$ : China, Sichuan prov, Gonia Shan Moxi, VII.1992 (LM). Paratype: + , China, Sichuan, Moxi Gongashan Mts, 28.VI-2.VII.1994, leg. Bolm, 1650 m, (NHMB).

DESCRIPTION. Head, prothorax and scutellum metallic bronze, labrum piceous, antennae fulvous with more or less darkened apical segments and black upperside of basal segment, elytra bronze with broad reddish outer margin, including apex (Fig. 19), pygidium black underside red (holotype) or black with reddish sides of abdominal segments, legs red. Pubescence white.

Head densely punctuate, strongly microsculptured, with convex and impunctate supraantennal swellings, labrum with 
a row of punctures on anterior margin. Antennae reach middle of elytra, proportions of antennal segments are as 15-10 9-17-19-16-19-13-13-13-15, preapical segments about twice as long as wide. Prothorax 1.1 times broader than long, broadest, side margins evenly rounded and bordered, but shortened on both ends, surface strongly and partly rugosely punctuate, interspaces narrow, shining. Scutellum elongate, almost parallel-sided with rounded apex. Elytra 1.55 times as long as wide, almost parallel-sided with broadly rounded apices, surface rather strongly punctuate in anterior half, punctures partly arranged in irregular rows, mostly in sutural area; there is a feeble ridge in anterior part, starting from

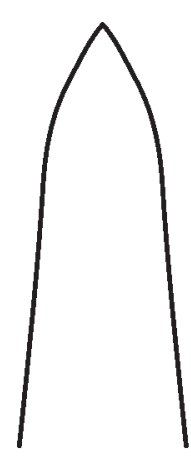

1

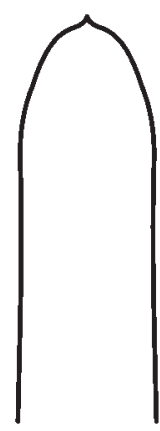

6

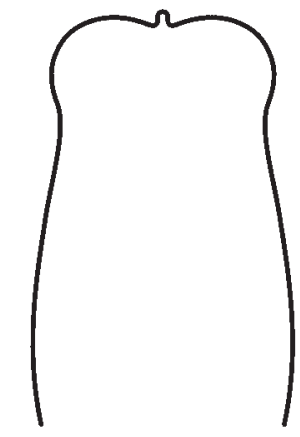

7

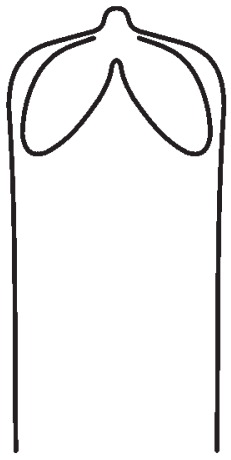

2

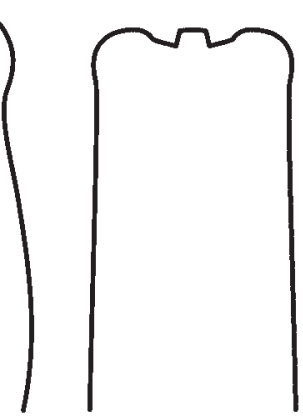

8

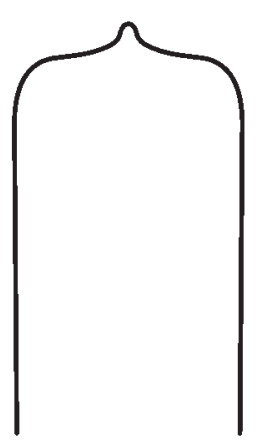

3

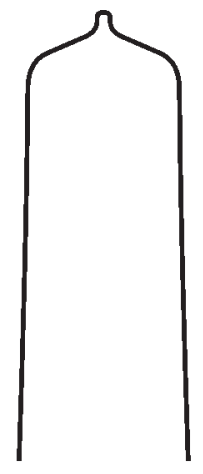

4

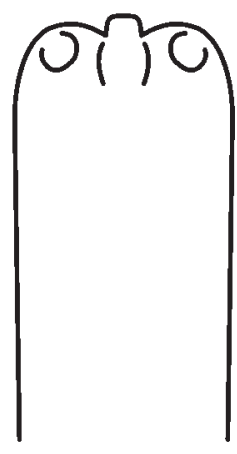

5

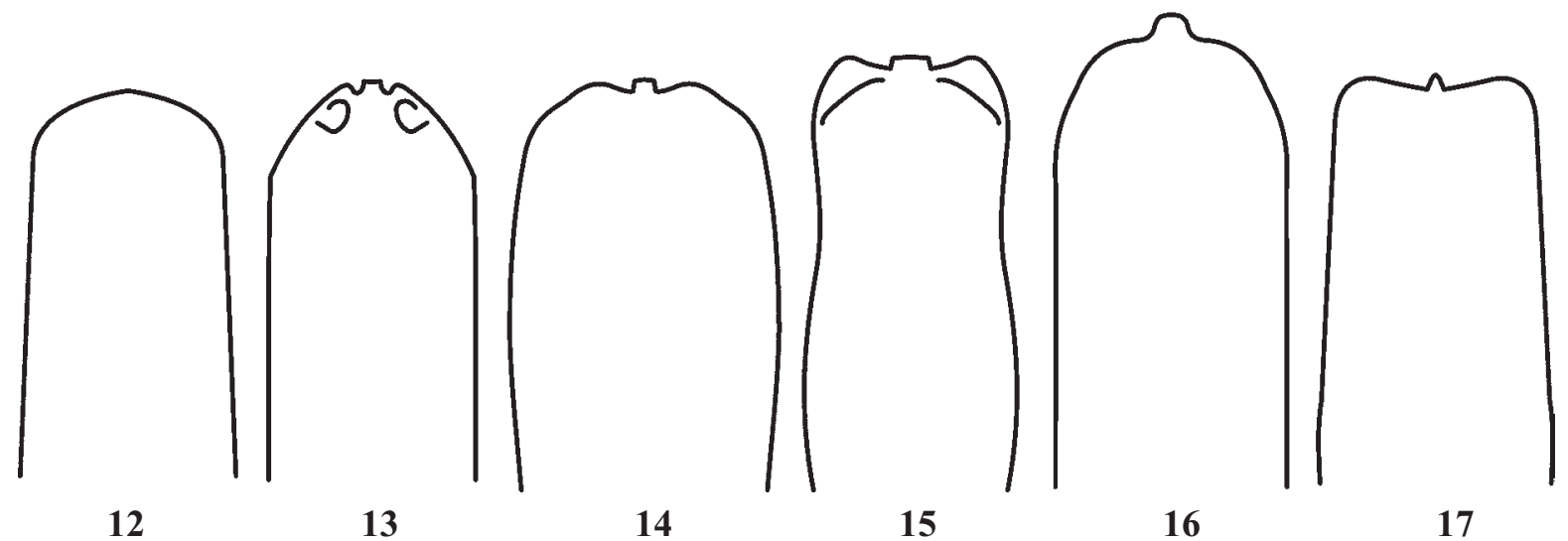

Figs 1-17. Aoria spp., apical half of aedeagus (before curving) from underside: $1-$ A. nucea; $2-A$. laosica sp.n.; $3-A$. floccosa; 4-A. cuprea sp.n.; 5-A. bowringi; 6-A. nigromarginata sp.n.; 7 - A. atra; 8-A. nigripennis; 9 - A. vietnamica sp.n.; $10-$ A.rufotestacea; $11-$ A.scutellaris; $12-$ A. fulva sp.n.; $13-$ A. antennata $; 14-$ A. nigripes; $15-$ A. bicoloripes; $16-$ A.thibetana; 17 - A. branciccii sp.n.

Рис. 1-17. Aoria spp., вершинная часть эдеагуса (перед изогнутостью), снизу: 1 - A. nucea; 2 - A. laosica sp.n.; 3 - A. floccosa; 4 - A. cuprea sp.n.; $5-$ A. bowringi; $6-$ A. nigromarginata sp.n.; 7 - A. atra; 8 - A. nigripennis; 9 - A vietnamica sp.n.; 10 - A.rufotestacea; $11-$ A.scutellaris; $12-$ A.fulva sp.n.; 13 - A. antennata; $14-$ A. nigripes; $15-$ A. bicoloripes; $16-$ A. thibetana; 17 - A. branciccii sp.n. 
humerus; hairs long, erect, partly arranged in rows. Length of body $6.6-7.6 \mathrm{~mm}$.

DIAGNOSIS. This is single species of the genus having metallic bronze elytra with red margins; also a form of scutellum is rather unusual.

\section{Aoria (s.str.) panfilovi Medvedev sp.n.} Fig. 24.

MATERIAL. Holotype ( + ): China, NW Sichuan, Guansian, 9.iv.1957, leg. D.Panfilov (LM).

DESCRIPTION. Head red with labrum and spots near eyes black, antennae black with segments $2-4$ more or less reddish, prothorax red with black spot before red scutellum, elytra black with small humeral spot and extreme apex red (Fig. 24), breast including prosternum black, abdomen including tergites red with two black spots in middle of the first sternite, legs black, pubescence fulvous.

Head strongly punctuate and finely microsculptured, with small supraantennal swellings. Antennae reach middle of elytra, proportions of segments are as 16-9-13-21-20-1518-15-15-15-19, preapical segments slightly thickened, about 2,5 times as long as wide. Prothorax 1.1 times as wide as long, with sides rounded, unmargined and broadest in middle, surface strongly punctate, with narrow microsculptured interspaces. Scutellum elongate triangular, punctuate. Elytra 1.5 times as long as wide, parallel-sided with broadly rounded apices, surface finely punctuate, especially behind middle, punctures confused, but partly arranged in irregular rows, basal convexity well developed, there is also humeral ridge going to middle of elytra. Length $7.3 \mathrm{~mm}$.

DIAGNOSIS. Differs from all knoun species with unusual color of upperside, inckluding black spot on prothorax and large size.

\section{Aoria (s.str.) nigromarginata Medvedev sp.n.}

Figs 6, 25-26.

MATERIAL. Holotype ( $0^{7}$ ): [China], Kuatun, $27^{\circ} 40^{\prime} \mathrm{N}, 117^{\circ}$ 40'E, 2300 m, 25.III. 1938, leg. J.Klapperich (LM). Paratype: $0^{\top}$, same locality, 25.V. 1938 (LM).

DESCRIPTION. Head and upperside red fulvous, 6 apical antennal segments, black stripe on sides of elytra (holotype, Fig. 25), sometimes strongly widened and developed also along suture (paratype, Fig. 26), underside including prosternum and legs black, in paratype prothorax with small round black spot in middle, pubescence fulvous.

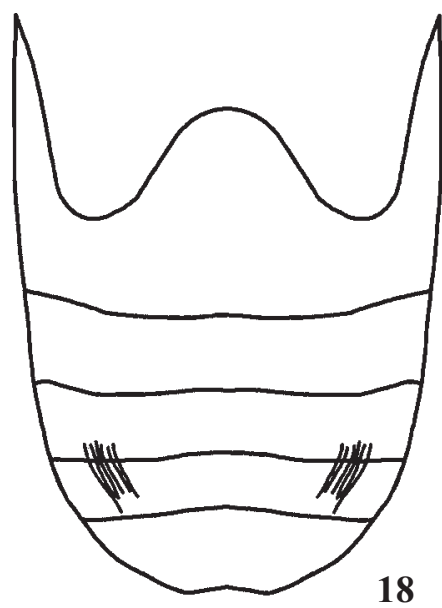

18

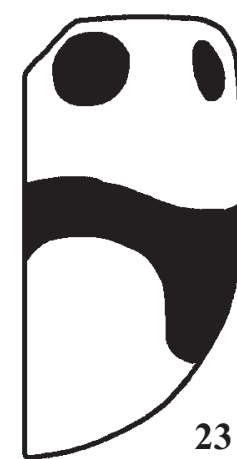

23

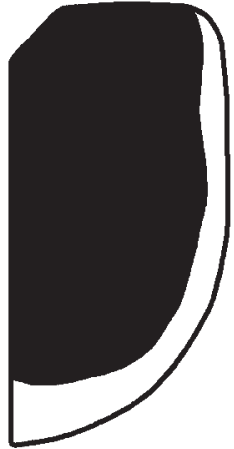

19
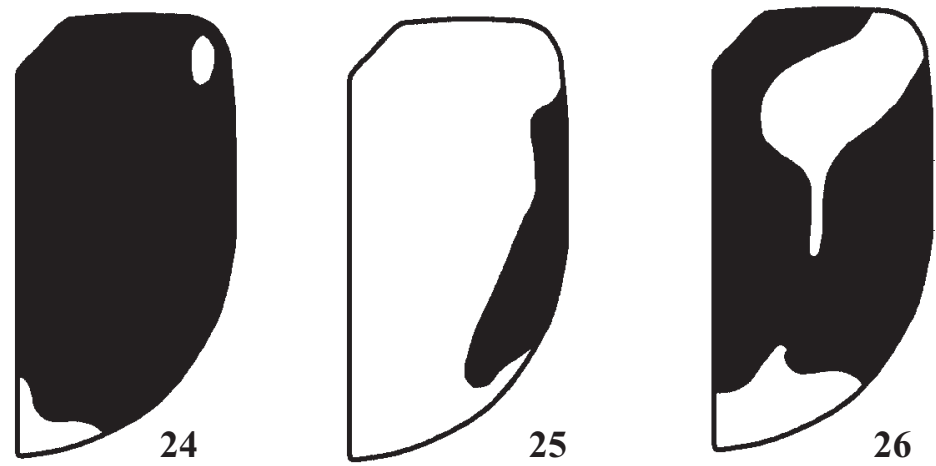

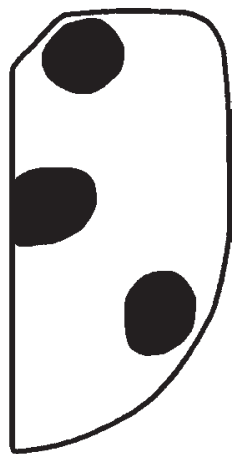

21

Figs 18-26. Aoria spp.: 18 - abdominal brushes of $0^{7} ; 19-26$ - elytral pattern; 18 - A. floccosa; 19 - A. nigripennis; 20-23 A. bowringi; $24-$ A panfilovi sp.n.; 25-26-A. nigromarginata sp.n.

Рис. 18-26. Aoria spp.: 18 - брюшные щёточки у о; 19-26 - рисунок надкрылий; 18 - A. floccosa; 19 - A. nigripennis; 2023 - A. bowringi; $24-$ A. panfilovi sp.n.; 25-26-A. nigromarginata sp.n. 
Head finely and densely punctuate on frons and vertex, much more sparsely on clypeus, all interspaces microsculptured, antennal spellings large and strongly convex, anterior margin of clypeus slightly concave. Antennae reach anterior quarter of elytra, proportions of segments are as 15-7-14 22-19-16-16-15-15-15-17, 6 apical segments about 1.2 1.3 times as long as wide. Prothorax 1.3 times as wide as long, with sides rounded, unmargined and broadest in middle, surface with moderately strong and dense punctures, their interspaces finely microsculptured, larger than punctures. Scutellum elongate triangular with truncate apex, punctuate. Elytra 1.25 times as long as wide, parallel-sided with broadly rounded apices, surface not strongly and confusedly punctuate, partly arranged in irregular rows, basal convexity very feeble, humeral ridge absent. Apex of aedeagus rounded with short truncate protuberance (Fig. 6). Length of body 6.2-6.3 $\mathrm{mm}$.

DIAGNOSIS. Resembles a little typical form of $A$. annulipes, having red elytra with black margin, differs with other color of elytra, black spot on prothorax, other sculpture of elytra and large size.

\section{Aoria (s.str.) vietnamica Medvedev sp.n.}

Fig. 9.

MATERIAL. Holotype (OT): Vietnam, Cuc Phuong, 24.IV.1975, leg. L. Medvedev (LM). Paratype: + , same locality and date (LM).

DESCRIPTION. Head black with reddish clypeus, labrum and maxillar palpi, antennae black with segments 1-4 red, prothorax black with anterior and posterior margins more or less reddish, scutellum red, elytra fulvous with sutural area reddish, underside including prosternum and abdominal tergites including pygidium red, femora red, tibiae and tarsi piceous to black, pubescence fulvous.

Head sparsely punctuate, especially on clypeus, microsculptured, supraantennal swellings feeble, anterior margin of clypeus very feebly concave. Antennae reach middle of elytra, proportions of segments are as 13-7-12-13-1313-13-13-11-10-13, preapical segments about 2 times as long as wide. Prothorax 1.25 times as wide as long, broadest in middle, sides rounded and unmarginate, surface net densely punctuate, with finely microsculptured interspaces and sparse erect hairs. Scutellum trapeziform, densely punctuate. Elytra 1.3 times as long as wide, parallel-sided with broadly rounded apices, surface without basal convexity with regular rows of punctures, convex interspaces and sparse erect hairs. Aedeagus - Fig. 9. Length of body $4.3-4.7 \mathrm{~mm}$.

DIAGNOSIS. Near A. rufotestacea, differs with color of prothorax and elytra and other form of aedeagus.

\section{Aoria (s.str.) martensi Medvedev sp.n.}

MATERIAL. Holotype ( $($ ): China, Shaanxi Prov, Taibai Shan above Haushenzi, 1700-2600 m, 9.VI--3.VII.1998, leg. P.Jager \& J. Martens (SMNS). Paratype: + , same locality and date (LM).

DESCRIPTION. Dark red, head and prothorax darker than elytra, light piceous, upperside with feeble metallic sheen, labrum and antennae fulvous or apical antennal segments slightly darkened, underside more or less darkened on breast and middle of abdomen, legs reddish with apices of femora darker, pubescence white.

Head strongly punctate, supraantennal swellings very small, labrum microsculptured, with a row of deep punctures near anterior margin, clypeus with feebly concave anterior margin, vertex impressed in middle, sparsely pubescent. Antennae reach anterior quarter of elytra, proportions of segments are as 13-7-9-11-12-13-13-10-11-11-16, preapi- cal segments about twice as long as wide. Prothorax 1.3 times as wide as long, broadest before middle, sides rounded and unmargined, surface strongly and densely punctate, with narrow, convex and shining interspaces. Scutellum trapeziform with rounded apex, finely punctate, shining, and not pubescent. Elytra 1.4 times as long as wide, slightly widened to behind, surface with well developed basal convexity, postbasal impression, short ridge starting from humerus, elongate impression before middle, just after humeral ridge, with very irregular rows, punctures, deep and dense in basal part, but much sparser and quite feeble apically and along suture, pubescence very sparse and erect. Length of body $5.3-6.1 \mathrm{~mm}$

DIAGNOSIS. Resembles A. gracilicornis, differs in larger size, different pubescence of upperside, quite other sculpture of elytra and partly in color.

\section{Aoria (s.str.) fulva Medvedev sp.n.}

Fig. 12

MATERIAL. Holotype ( $\left(\sigma^{7}\right)$ : China, Shaanxi, $120 \mathrm{~km}$ E Xi an Hua Shan, 3-4.VI.1992, leg. J.Turna (LM). Paratypes: 5 ex., same locality (LM)

DESCRIPTION. Fulvous or pale fulvous with antennal segments, 5-11 piceous to black, pubescence white.

Head strongly punctate, especially on frons, supraantennal swellings very feeble, labrum microsculptured, with a row of punctures on anterior margin, clypeus with almost straight anterior margin. Antennae reach middle of elytra, proportions of segments are as 10-5-10-11-11-11-1111-11-11-13, preapical segments about 4 times as long as wide. Prothorax as long as wide, broadest in middle, sides rounded and unmargined, surface densely punctate with narrow shining interspaces. Scutellum elongate triangular with rounded apex, punctate. Elytra 1.5 times as long as wide, parallel-sided with broadly rounded apex, densely and confusedly punctate with traces of rows near suture, without basal elevation. Aedeagus (Fig. 12) broadly rounded on apex with scarcely visible apical tip. Length of body $3.5-3.7 \mathrm{~mm}$.

DIAGNOSIS. Differs well with small size, fulvous body and form of aedeagus from all known species of the genus.

\section{Aoria (s.str.) thibetana Pic, 1928}

\section{Fig. 16.}

REMARK. Unclear species, described very shortly and not included in existing keys to Chinese species [Gressitt \& Kimoto, 1961, Tan Wang Zou, 2005]. But I can study 3 specimens from Yunnan, determined by $\mathrm{S}$. Kimoto as $A$. thibetana. I am not sure that these specimens are real $A$. thibetana, but prefer to give a shape of aedeagus (Fig. 16).

\section{Aoria (s.str.) annulipes Pic, 1935}

REMARK. Typical $A$. annulipes has bicolor elytra: red with black sides. Gressitt and Kimoto [1961] include A. pectoralis and A. pectoralis var. diversipes Pic, 1935, both having entirely red upperside, in synonyms to $A$. annulipes. It seems, that these authors studied Pic's types, but in their key nothing mentioned, that nominative form has bicolor elytra.

\section{Aoria (s.str.) brancuccii Medvedev sp.n.}

\section{Fig. 17.}

MATERIAL. Holotype $\left(\sigma^{7}\right)$ : NE India, Meghalaya, $3 \mathrm{~km} \mathrm{E}$ Tura, $25^{\circ} 30^{\prime} \mathrm{N}, 90^{\circ} 14^{\prime} \mathrm{E}, 1150 \mathrm{~m}, 4 . V .1999$, leg. Dembicky \& Pacholátko (NHMB). 
DESCRIPTION. Black, maxillar palpi and 4 basal antennal segments fulvous, labrum, vertex, broad basal band on elytra and abdominal tergites except pygidium red. Pubescence fulvous.

Head distinctly punctuate and pubescent, not microsculptured, supraantennal swelling indistinct, anterior margin of clypeus slightly concave. Proportions of antennal segments are as 12-6-10-14-14-12-15-15 (next segments absent), segments 6-8 slightly thickened, about 3.5 times as long as wide. Prothorax 1.5 times as wide as long, broadest in middle, with sides rounded and unmargined, surface with very dense punctures, interspaces narrow, without microsculpture, but with microscopical punctures. Scutellum trapeziform with truncate apex, finely punctuate. Elytra 1.25 times as long as wide, broadest in shoulders and narrowed posteriorly to narrowly rounded apices, with strong humeral tubercles, but without basal convexity and any ridges, punctures arranged in rather regular rows, which are not very distinct among densely punctuate interspaces, pubescence dense, not arranged in rows. Apex of aedeagus truncate and slightly concave, with small central tip (Fig. 17). Length of body $4.3 \mathrm{~mm}$.
DIAGNOSIS. Resembles A. nigripes Baly, 1860, differs in having red vertex and basal band of elytra.

\section{References}

Eroshkina G.A. 1987. [Revision of genera Scelodonta Westwood and Aoria Baly (Chrysomelidae, Eumolpinae) of Vietnam fauna] // Entomofauna Vietnama. Moscow: Nauka. P.41-48 [in Russian].

Gressitt J.L. \& Kimoto S. 1961. The Chrysomelidae (Coleopt.) of China and Korea. Part $1 / /$ Pacific Insects Monograph. Honolulu. Vol.1A. P.1-299

Kimoto S. \& Gressitt J.L. 1982. Chrysomelidae of Thailand, Cambodia, Laos and Vietnam. III. Eumolpinae // Esakia. Vol.18. P.1-141.

Medvedev L.N. 1983. [New data on foodplants of leafbeetles (Coleoptera, Chrysomelidae) in Vietnam] // Fauna i ekologiya zhivotnykh Vietnama. Moscow: Nauka. P.145-148 [in Russian].

Medvedev L.N. \& Dang Thi Dap 1982. Trophical connections of Chrysomelidae in Vietnam // Animal world of Vietnam. M.: Nauka. P.84-97.

Moseyko A. \& Sprecher E. 2010. Eumolpinae. // I. Löbl \& A. Smetana (eds.). Chrysomeloidea. Catalogue of Palaearctic Coleoptera. Vol.6. Apollo Books. P.619-643.

Tan J. 2005. Coleoptera, Eumolpidae, Eumolpinae // Fauna Sinica. Insect. Beijing: Science Press. Vol.40. P.1-415. 